\title{
Ligate-and-Resect Technique for Resection of a Large Pseudo-Pedunculated Subepithelial Lesion in the Ascending Colon
}

\author{
Sofia Silva Mendes ${ }^{a-c}$ Rolando Pinho ${ }^{b}$ Sónia Leite ${ }^{b}$ Ana Ponte ${ }^{b}$ Joana Silva ${ }^{b}$ \\ Jaime Rodrigues $^{\mathrm{b}}$ Mafalda Sousa $^{\mathrm{b}}$ João Carvalho ${ }^{\mathrm{b}}$ \\ ${ }^{a}$ Department of Gastroenterology, Braga Hospital, Braga, ${ }^{b}$ Department of Gastroenterology, Centro Hospitalar de \\ Vila Nova de Gaia/Espinho, Vila Nova de Gaia, and ' Life and Health Sciences Research Institute (ICVS), School of \\ Medicine, University of Minho, Braga, Portugal
}

Keywords

Lipoma · Colon · Polypectomy

Técnica de ligadura e resseção para a exérese de uma lesão pseudo-pediculada volumosa no cólon ascendente

\section{Palavras Chave}

Lipoma · Cólon · Polipectomia

A 66-year-old male with a medical history of diabetes and hypertension was referred for resection of a large pedunculated lesion in the ascending colon, found in a screening colonoscopy. During the second colonoscopy, a pseudo-pedunculated subepithelial lesion with $35 \mathrm{~mm}$ (Fig. 1a, b) and a long and thick pseudo-stalk (Fig. 1c, d) was found in the ascending colon. The mucosa over the lesion was congestive with discrete erosions and a slight yellow tone from the subepithelial lesion was evident. With a dual channel colonoscope (Olympus, CF-2T160I), an endoloop (Olympus, MAJ-254) was placed near the base of the pseudo-stalk (Fig. 2a). Using the loop-over-

\section{KARGER}

E-Mail karger@karger.com www.karger.com/pjg
(C) 2017 Sociedade Portuguesa de Gastrenterologia Published by S. Karger AG, Basel

Karcer Open access

This article is licensed under the Creative Commons AttributionNonCommercial-NoDerivatives 4.0 International License (CC BYNC-ND) (http://www.karger.com/Services/OpenAccessLicense) Usage and distribution for commercial purposes as well as any distribution of modified material requires written permission.
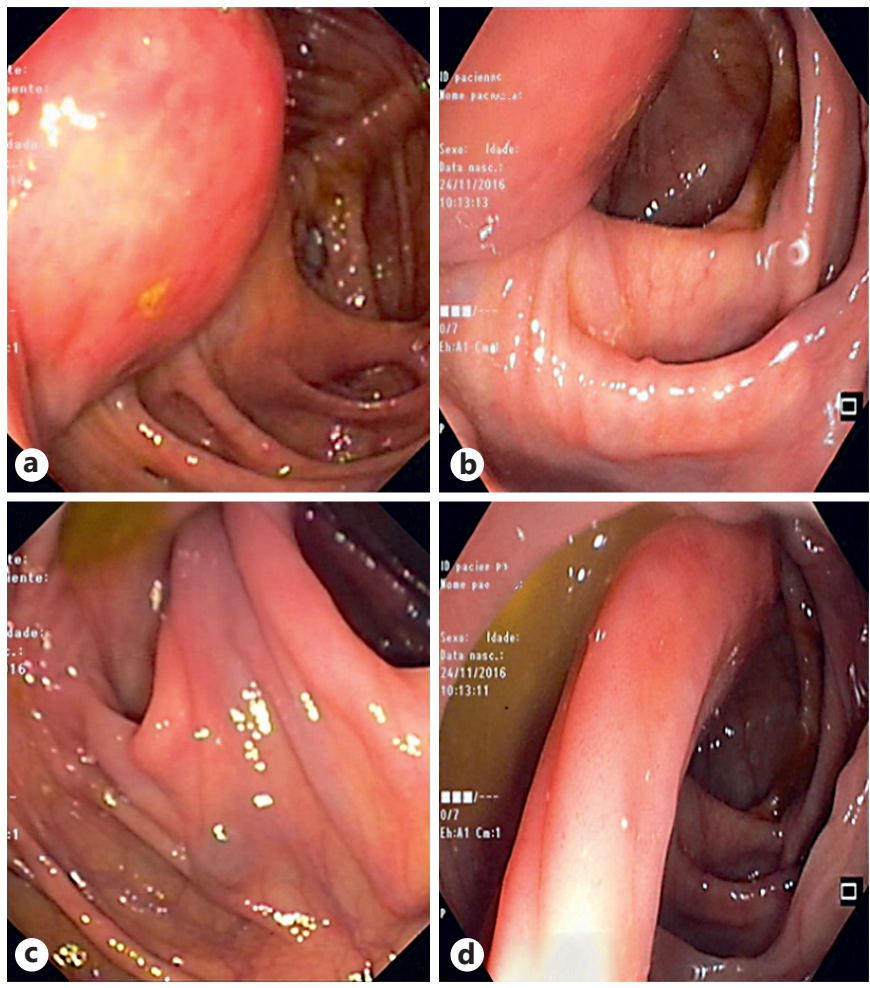

Fig. 1. Endoscopic appearance of the pseudo-pedunculated subepithelial lesion on the ascending colon. $\mathbf{a}, \mathbf{b}$ Head of the lesion. c, d Pseudo-stalk.
Dr. Sofia Silva Mendes

Department of Gastroenterology, Braga Hospital Rua das Sete Fontes PT-4710-243 Braga (Portugal)

E-Mail sofiadasilvamendes@gmail.com 

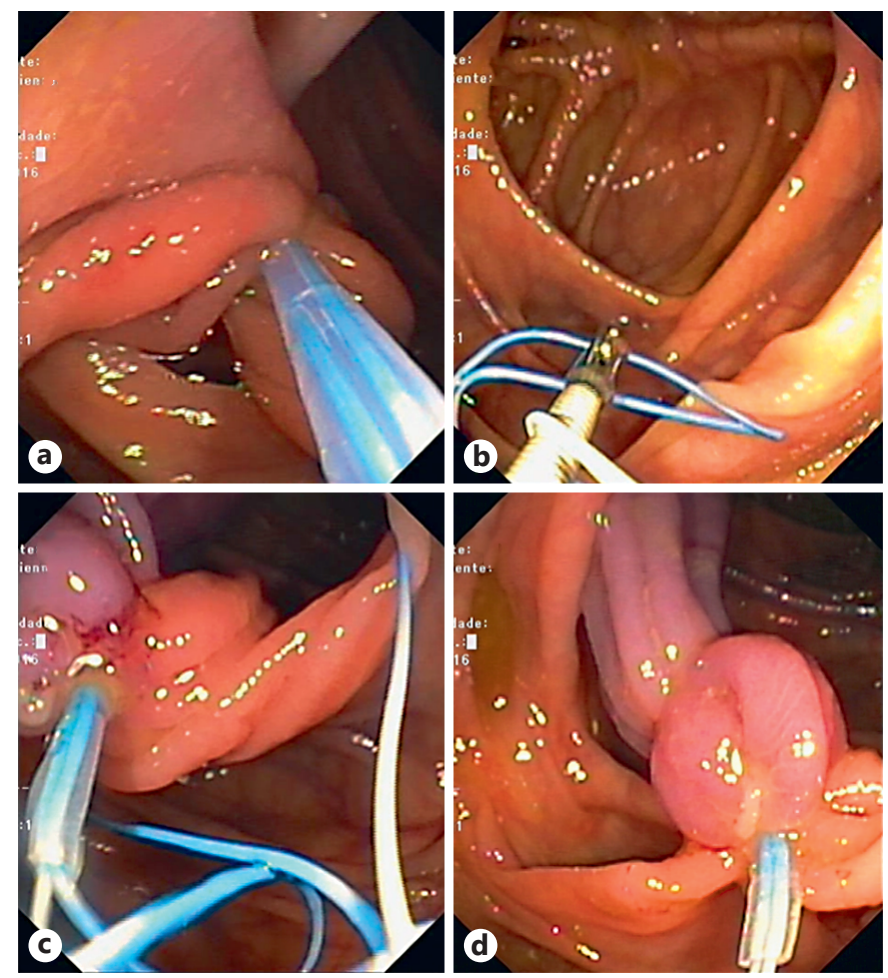

Fig. 2. Loop-over-loop technique. a Placement of the first endoloop. b, c Grasping of the first endoloop using a grasping forceps inside a second endoloop to place the second endoloop below the first one. $\mathbf{d}$ Tightening of the second endoloop with visible congestion of the mucosa above.

loop technique, a second endoloop was placed below the first endoloop (Fig. 2b). A grasping forceps placed in the second working channel was used to pull the first endoloop and retract the lesion into the second endoloop (Fig. 2c, d). Resection of the lesion with a conventional oval snare was then safely performed above the two endoloops (Fig. 3a, b) and the lesion was captured (Fig. 3c, d) for histological analysis, which revealed complete resection of a 30-mm lipoma with non-dysplastic overlying mucosa.

Colonic lipomas are benign adipose tissue tumors predominantly arising from the submucosal layer, with a reported incidence of approximately $0.2-4.4 \%$ [1]. In most cases, colonic lipomas are asymptomatic and found incidentally [1]. Nevertheless, large lipomas $(>20 \mathrm{~mm})$ are more prone to cause abdominal pain, diarrhea, or constipation, and less frequently, gastrointestinal bleeding, intestinal occlusion, and intussusception [1]. In this case, the lipoma was felt prone to complications as it was large and very mobile from its pseudo-pedunculated morphol-
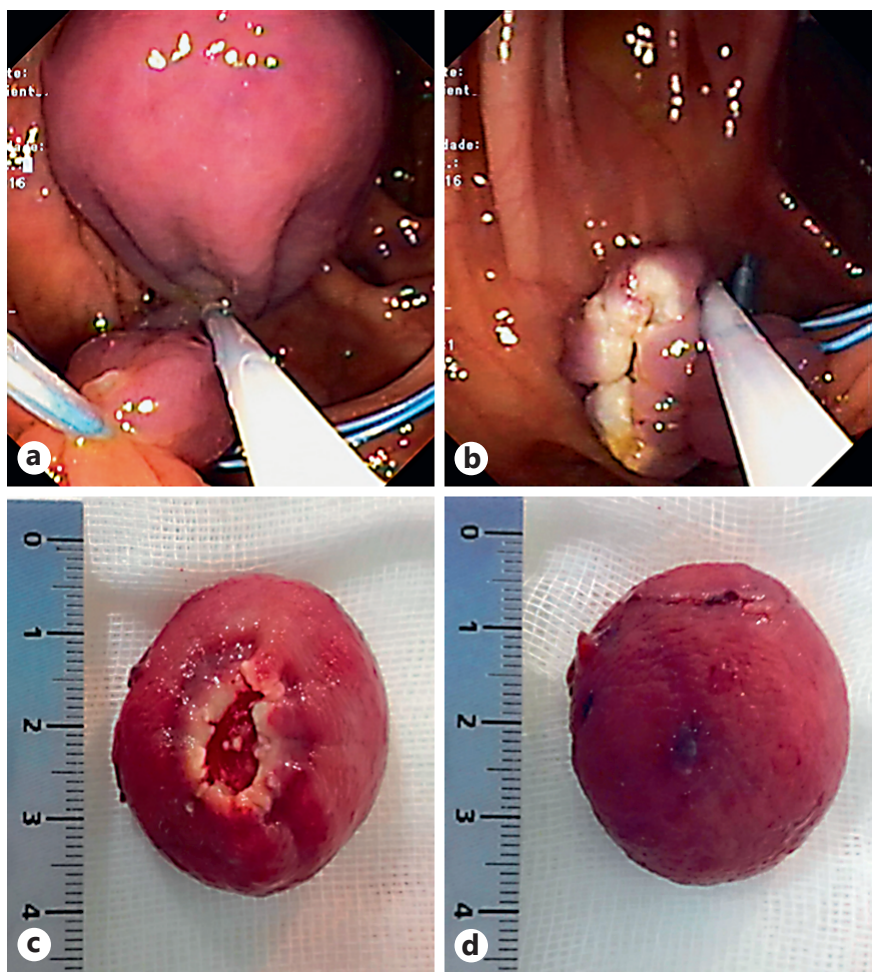

Fig. 3. Resection of the lesion. a Resection of the subepithelial lesion above the two endoloops. b Polypectomy scar immediately after resection. Apical (c) and base aspects (d) of the lesion.

ogy and already had an overlying congestive and eroded mucosa resulting from mechanical trauma from peristalsis. As there is no consensus on the resection or surveillance of asymptomatic large colonic lipomas, the patient must be involved in the decision. Resection is usually the preferred option because of the fear of complications and the relative low risk of the endoscopic techniques when the characteristics of the lesion are favorable, as in this case [1]. One of the most common practices for the treatment of large subepithelial colonic lipomas is the ligateand-let-go technique along with removal of one fragment of the lesion for histological analysis using the unroofing technique [2-4]. The use of two endoloops increases the efficacy of this technique and reduces the risk of perforation [5]. In this case, the long pseudo-stalk allowed the safe resection of the lesion after placement of the two endoloops, with the advantages of histological characterization of the entire lesion and higher complete resection rate. Thus, in selected cases, this approach may be an alternative to consider to the ligate-and-let-go technique. 
This study did not require informed consent nor review/approval by the appropriate ethics committee.
The authors declare no conflicts of interest.

\section{References}

1 Nallamothu G, Adler DG: Large colonic lipomas. Gastroenterol Hepatol 2011;7:490-492.

2 Ponte A, Pinho R, Rodrigues A, Vale S, Cidade C, Silva J, Rodrigues J, Sousa M, Carvalho J: Endoscopic resection of large gastrointestinal lipomas: loop-and-let-go technique with some twists. Gastroenterol Hepatol 2016;pii:S0210-5705(16)30063-2.

3 Veloso R, Pinho R, Rodrigues A, Pais T, Fernandes C, Carvalho J, Fraga J: Endoloop ligation ("loop-and-let-go") of a large ileal lipoma by balloon-assisted enteroscopy. Endoscopy 2012;44:176.
4 Ponte A, Pinho R, Vale S, Fernandes C, Ribeiro I, Silva J, Carvalho J: Resection of a large ileal lipoma exhibiting ball-valve prolapse into the cecum with a grasp-to-retract, ligate, unroof, and let-go technique. Endoscopy 2015;47:E215-E216.

5 Lee SH, Park JH, Park DH, Chung IK, Kim HS, Park SH, Kim SJ, Cho HD: Endoloop ligation of large pedunculated submucosal tumors (with videos). Gastrointest Endosc 2008;67:556-560. 